\title{
Identity and Belonging in Post-Apartheid South Africa: The Case of Indian South Africans
}

\author{
Goolam Vahed and Ashwin Desai* \\ Department of Historical Studies, MTB 211, University of KwaZulu-Natal, King George VAve, \\ Durban, 4000, Kwa-Zulu Natal, South Africa \\ E-mail:vahedg@ukzn.ac.za \\ "Department of Sociology, Rhodes University, \\ P.O. Box 94, Grahamstown, 6140 South Africa \\ E-mail: conferencesanpad@yahoo.com
}

KEYWORDS Diaspora. Race. Ethnicity. Class. Indians. Affirmative Action

\begin{abstract}
This paper examines Indian identities in the post-apartheid period, focusing in particular on the vexed issues of identity and belonging. The inauguration of Nelson Mandela as President of a non-racial democratic South Africa on 10 May 1994 denoted the de-territorialisation of old apartheid racial identities. Race separateness was no longer codified in law and common citizenship was meant to glue all into a South African "nation". The process has been far from simple as 'Indian' identity has been constructed, deconstructed and re-made over the years. A central dynamic of this process has been the tension between the way the state has tried to define identity. In the postapartheid period too, there is unraveling of Indian identities in response to external factors such as the rise of the BJP (Bharatiya Janata Party) in India, the struggle of Tamils in Sri Lanka, and the Global War on Terror, while the state continues to play an interventionist role through its race-based affirmative action policies. All of this underscores tensions among Indians on how best to assert their belonging in Africa. As this article is being written there is a growing interest in the commemoration of 150 years since the arrival of Indian indentured labourers in South Africa in 1860. The present conjuncture opens possibilities to debate issues of identity and belonging. If access to resources continues to be defined exclusively by race then one can expect increasing frustration on the part of the poors who will most likely be susceptible to racial and ethnic overtures. On the other hand, the middle classes, living in the same gated communities and enjoying the same sports like cricket and golf, may witness bonding across racial lines.

Just as none of us is outside or beyond geography, none of us is completely free from the struggle over geography. That struggle is complex and interesting because it is not only about soldiers and cannons, but also about ideas, about forms, about images and imaginings (Said 1993: 7).
\end{abstract}

As this article is being written there is a growing interest in the commemoration of 150 years since the arrival of Indian indentured labourers in South Africa in 1860 . The process is already contested with heavily charged debates over who should drive the commemoration and to what ends, given the religious, ethnic, regional, linguistic, and class diversity of the approximately 1.2 million Indian South Africans. What is it that should be remembered, celebrated, and commemorated? If commemoration is to reflect a collective memory, how is this to be stitched together? Can it and should it be a single narrative? How will this honouring of the past avoid ghettoisation? And what does this (ethnic / racial) commemoration mean in a country whose constitution is committed to non-racialism? How should the act of "remembering" tell of the country of origin?

These debates are a valuable lens through which to grasp the story of Indian South Africans in the post-apartheid moment and the vexed issues of identity and belonging.
Building on and extending the policy of segregation the National Party institutionalised racial separation through the guiding hand of apartheid from 1948 to 1994, a policy that 'sliced and diced South Africans, decreeing that they were many peoples, establishing separate institutions for the separate peoples, and fighting consolidation of one people' (MacDonald 2006: 92).

If apartheid had attempted to lock racial identities into sealed compartments then South Africa's first non-racial election in 1994 signalled that this trajectory was to end. The inauguration of Nelson Mandela on 10 May 1994 denoted at one level the de-territorialisation of old apartheid identities. All South Africans had the right to vote and freedom of movement. Race separateness was no longer codified in law and common citizenship would glue all into a South African "nation", heralding a vindication of the ANC's long struggle, in the words of Govan Mbeki, 'to form one people, to be represented in one parliament in one country ... to forge one nation, 
a non-racial democracy in a unitary state' (Mbeki 1992: 26). Would New Identities Unhinged from the Past Come to Fruition?

This paper examines Indian identities in the post-apartheid period. Whereas shared experiences under apartheid reinforced "Indianness", is non-racialism taking root among Indians? Are identities fragmenting along class-based lines? Are historic socio-political-economic divisions reflected in the identities being reproduced or are they closing ranks? Can Indians forge an identity of their own making and what will its content be? What is the role of a resurgent India in all of this?

\section{THE RAINBOW NATION}

'We have made Italy, now we have to make Italians'

- D’Azeglio (cited in Hobsbawm 1996: 257)

How would this South Africanism be constructed in the post-apartheid period? Already, the post-1990 talk was of "rainbowism", Archbishop Desmond Tutu's "master image" of the unfolding events that would see the four "nations" maintain their boundaries even as they were welded together to build the nation (Coetzee 1995). Rainbowism would even allow for further flowering of identities. As F.W. de Klerk, apartheid South Africa's last head of state, put it in October 1990:

The "New South Africa" would recognise the reality of the need for people and communities to remain themselves and be able to preserve the values that are precious to them-so that the Zulus, the Xhosas, the Sothos and the whites can feel secure in their distinctiveness (Sparks 1994: 128).

De Klerk's "promise" was to have some vindication. Rather than progressively fading away, apartheid racial categories were to be secured through state sanction. Amidst the whiff of de-territorialisation were strong winds of reterritorialisation.

The preamble to the post-apartheid constitution of 1996 bequeathed the country 'to all who lived in it,' while recognising the multicultural/racial/ethnic nature of the society. Whereas the apartheid government exploited diversity to separate and dominate, the new ANC government provided space for South Africans to recreate themselves within particular cultural, racial, and ethnic milieus, and to be brought together as equals in celebration of unity through diversity in a non-racial state. While not bounded by any precise definition, "non-racialism" was inscribed as a founding value in the constitution.

There would be no Ministry of Indian Affairs or Minority Affairs for that matter. But redress was to be conducted along the lines of race. Forms would ask one to tick:*African/Black, *Coloured, *Indian/Asian, *White. There is no category "South African". The past fifteen years has seen the government labouring under the contradiction of 'narrating the nation' through notions of unity through respecting diversity.

While apartheid era racial categorisation no longer denied citizens the right to vote or regulate whom they could marry, they could be used for the allocation of resources. There were historical parallels with apartheid: for volkskapitalisme, read Black Economic Empowerment (BEE); for job colour bar, affirmative action. There was more to this than form-filling. Rainbowism encouraged displays of racial separateness. It was heralded and valued at national events. To put this on display was to be a correct rainbow person. There was little space for those who consciously chose to erode racial barriers by throwing off apartheid categorisations that had hemmed-in their identities to one of four nations.

If the scrapping of the Population Registration Act in 1990 broke the back of legal provisions that made for Indian identity, what would be the basis for its congealing in this changing political conjuncture? Beyond local developments there was one particular change for Indian South Africans and that was at the level of the global.

During the years of apartheid, India led the boycott of South Africa and became increasingly distant for most Indian South Africans. A negligible number of Indians visited or settled in South Africa. This was a throwback to Mohandas Gandhi's 1913 agreement with Prime Minister Smuts to stop further immigration, the stance taken by independent India to isolate apartheid South Africa, and the Nationalist Party's insistence until 1961 that the preferred option for Indians was repatriation. So, for example, there were no direct flights to India, no sporting contacts and goods from India country had to be routed via a third country.

As the official renewal of linkages unfolded, how would Indian South Africans react to their country of origin? This is a theme we return to later in the paper.

'I have been a stranger in a strange land' (Moses: Exodus 2:22; American King James Verson) 
A possibly troubled relationship with host societies, suggesting a lack of acceptance and/ or the possibility that another calamity might befall the group (Cohen 1997, 26).

Point seven of Robin Cohen's nine point typology of diaspora is in many senses a thread that links the apartheid and post-apartheid moments.

The majority of the Indians did not vote for the ANC in 1994 and 1999. They voted in larger numbers for the ANC in 2004 but in 2009 their vote was evenly distributed. Voting patterns reflect internal class divisions to a considerable extent. Support for the ANC is mainly from higherincome Indians, who may benefit from affirmative action and BEE. Working-class Indians, on the other hand, feeling threatened and marginalized, have tended to support minority parties. Support for tricameral parliament politician Armichand Rajbansi and his Minority Front remains strong. At a rally in Phoenix in February 2009 he drew a crowd of close to 2000. To loud applause he said that election results proved that 'the MF is the king of Phoenix. Never before in the history of the New South Africa has the country needed a South African voice for minorities.' He condemned affirmative action for 'having a negative impact on the country and the people who are in charge of applying the policy are applying it unfairly' (Rising Sun 4-10 February 2009).

Part of the explanation for ambivalence towards the ANC also lay in the historically uneasy relationship of Indians and Africans. Between the 1946 Passive Resistance and the turn to an alliance with the ANC in the early 1950 s there was a violent racial conflagration between Indian and African in January 1949. ${ }^{1}$ This violent experience haunted Indo-Africans relations throughout the period of apartheid. Another outbreak of violence against Indians in Inanda in 1985 was a reminder of their vulnerability.

Despite the story of the Congress Alliance, Black Consciousness and the heady days of the United Democratic Front in the 1980s, the well chronicled narrative of non-racialism, "the unbreakable thread' as Julie Frederickse (1990) put it, tension between Indian and African was a persistent feature of the landscape and continues into the present. Although the majority of Indian South Africans have indentured roots and shopkeepers make up a tenth of working Indians at present, the stereotype of the exploitative trader remains strong.
This thread of Indo-African tension was brought into the public domain in 2002 when playwright Mbongeni Ngema's 2002 song in Zulu, 'AmaNdiya' ("Indian"), attacked Indians for their alleged unwillingness to accept Africans as equals, for resisting change, being interested only in making money, and being exploitative. He protested the presence of post-1994 migrants from India and Pakistan and urged the "strong men" of the Zulu nation to stand up to Indians. Lyrics such as "we are faced with hardship and poverty because everything was taken by the Indians, but they turn around and exploit us" and "Indians are abusive to Black people, being more racist than Whites", sounded a clear warning to Indians.

George Simmel's 'The Stranger' (1908) sought to understand the roots of anti-Semitism against Jewish merchants in Europe. The Indian as "stranger" in South Africa was not restricted to 'the trader as stranger' but enveloped all, the majority of whom were workers. Relations between Indians and Africans remain delicately balanced. Apartheid aimed for rigid boundaries. The Congress Alliance was significant in developing an Indo-African politics, but as apartheid hardened this did not translate into a mass movement across the divide but at best met at the fingertips of (mostly middle class) leadership.

Interaction between Indians and Africans in the post-apartheid moment remains largely restricted to parent bodies at private schools and some coalescing around economic and political issues, but is largely superficial at the levels of day-to-day interaction and socialisation. Apartheid contributed to this distancing by legally separating "races" but questions of affirmative action and access to resources are reproducing old stereotypes in new ways.

Thrown into this mix is the rise of India as an economic and political force in the twenty-first century and the forces of globalization which have increased the speed of travel and communication and permit members of the diaspora to forge a transnational connection with the "homeland". What is the impact of this on local social relations and cultural identity?

\section{"HOMELAND"}

A collective memory and myth of the homeland...

An idealisation of the putative ancestral home.... (Cohen 1997, 26). 
Cohen's third and fourth points are relevant to the post-apartheid moment.

The demise of apartheid ended the isolation of global cultural and economic flows and coincided with India's emergence as a global power. A new wave of immigrants had entered the United States from the 1960s and some became fabulously wealthy, especially through the IT industry. Inside India the liberalisation of the economy generated new millionaires and Indian companies like Tata and Reliance were rapidly becoming global players. India was "shining" and Bollywood served as the advance guard of its global cultural reach. The world received images not of the villages of Gandhi's India but of an urbanised and affluent India. Indian South Africans met India in this moment of gloss and polish, an India basking in 'a rising tide of selfcongratulation' (Guha 2007: 719).

Indian South Africans, from the time that the first labourers landed on the shores of Port Natal in 1860, have undergone significant changes. Well over 95 percent regard English as their first language, tens of thousands have converted to Christianity, caste has eroded as a signifier for marriage, and cuisine, dress, and other markers of "Indianness" have mutated. While their everyday lives are increasingly distant from India, they remain "Indian" in the eyes of fellow South Africans and to themselves. The post-apartheid period has been witness to a search for "roots". This is evident in many parts of the world and is made easier by the communications revolution. The passion and intensity with which this is carried out is dependent on personal circumstances such as the political and cultural contexts, class position, and experiences of inclusion and exclusion. Connection to the "Homeland" has been kindled in a variety of ways.

The Natal Archives Depot in Pietermaritzburg has had to open on Saturdays because of increased demand from persons tracing their ancestry. Since the authors published Inside Indenture (2007) they have been inundated by requests for assistance to trace "roots". The following is typical.

>>> <msmoorad@webmail.co.za> 12/29/08 4:43 $\mathrm{PM} \gg>$

my name is mohammed saleem moorad-im from phoenix,durban.

$i$ saw your book-Inside Indenture at the library and im wondering how to

trace the origins of someone who came from India? $i$ have an elderly man at my musjid \& he was asking me how would he be able to locate the village/town from where his father came.

he gave me a few details- date of birth, register no., name etc. $i$ tried to

contact university of durban-westville as $i$ understand they did extensive research into this- but ive received no reply$i$ even sent a letter to the

editor of daily news, $i$ dont know if it got published, but $i$ have not received any feedback/reply. would you be able to assist me if $i$ gave you these details?

please reply br email or cell. jazakallah

This is augmented by some by visits to India, especially "spiritual" tourism to religious shrines by Hindus and Muslims, made easier by direct flights from Johannesburg to Mumbai. It has become popular to visit India in search of "roots" even among those who are not certain where their ancestors originated and the search is usually in vain. Discussions with a few who traced roots indicates that this was not so much to seriously re-link to the homeland but to satisfy a desire to see where their ancestors hailed from. For some it was a journey into the unknown, one that was an anticlimax.. Much of the image is a romantic one through satellite television that caters for both North (Sony, B4U and Zee TV) and South Indians (Sun TV and KTV). This is supported by regular screening of Bollywood movies in "mainstream" cinemas, DVD outlets, and pirated copies on street corners. Indian South Africans are able to 're-create their own fantasy structures of homeland [through] the collapse of distance on the information highway of cyberspace and a collective sharing of knowledge about the homeland' through web sites and search engines (Mishra 2007: 17). Class clearly determines the intensity of this (re) connection with homeland. Many 'heavy hitters', as a local newspaper described it, among Indian South Africans attended the seventh Pravasi Bharatia Divas (Global Indian Diaspora) Convention in Chennai in January 2009. The convention was described as ideal for 'networking and exploring one's ancestry' (Sunday Tribune Herald 4 January 2009).

The inaugural T20 Cricket World Cup played in South Africa in September 2007 captured the connection to India starkly. India emerged 
victorious after beating Pakistan in a tense final. Significantly, the Indian team was supported by thousands of South African Indians donned in Indian shirts and waving Indian flags. This irked many non-Indian South Africans who questioned their patriotism to South Africa. "Go Home if you are not proudly South African" was the message. The perception that Indians could never be real South Africans was reinforced. However, the reality is that India is viewed as an ancestral homeland to which there may be an emotional attachment but South Africa is "home". Supporting India did not mean being anti-South African. Many Indians are still angered by the fact that their own cricketing history played under the auspices of the South African Council on Sport (SACOS) which popularized the slogan "no normal sport in an abnormal society' has been virtually erased while those who played for white South Africa under apartheid Springboks continue to be lauded.

Most South African Indians have roots that are four to five generations deep in South Africa and are highly unlikely to emigrate to India. The few who can, mainly professionals, aspire to emigrate to the UK, Canada, Australia and US. Yet India has a certain newfound allure. Mishra's references to the creation of 'imaginary homelands from the space of distance...' (Mishra 2007: 16) seems to hold true. The impression one gets from cursory discussions with those searching for roots is pride in being linked to an ancient culture but no inclination to settle there. It is more about religious knowledge and experiences and sensory enjoyment like cricket, movies and music, and dance.

These developments raise questions about identity and belonging which have come to the fore in previous times, such as Gandhi's struggles against the British and especially when Indian became independent in 1947. Then too Indians in South Africa took pride in their Indian heritage. South Africa was home and India homeland. This suggests, as Parvathi Raman reminded us in her e-mail correspondence on 15 February 2009, 'any relationship with home for a diaspora community is in flux and subject to historical context.' There are differences between 1947 and 2009. The possibilities of 'imaging the homeland', as we point out above, are greater today because of technology and, as we discuss below, encouragement by the Indian government for people to think in these terms. In 1947 Nehru made it clear that
India was an independent nation-state part and parcel of the nonaligned movement and that Indians in the diaspora belonged to the countries where they lived. That was home.

1990 . For the first time in nearly 50 years the Indian consulate was on the doorstep.

\section{Persons of Indian Origin (PIO)}

It is not the lower-class migrant labourers in the Gulf region who are the primary targets.... It is also not the older merchant communities that form the target of policy. Rather, it is the new Hindu middle-class professional and entrepreneurial migrant especially in the United States that forms an important focus for Indian politics (van der Veer 2005: 285).

As early as 1973 the Indian government had inaugurated the category of non-resident Indian (NRI) for both economic and political reasons. The Hindu nationalist Bharatiya Janata Party (BJP) extended NRIs by introducing the People of Indian Origin (PIO) card or dual citizenship in 1998 which makes it easier to maintain relations with India and extend that affective link into a material one (Brown 2006: 159). The economic reason was to raise foreign exchange while the political rationale is significant. It was part of a wider "effort by the right-wing Indian government to convert diverse, often wealthy populations of Indian origin into a permanently attached "expatriate nation", or a "global Indian family' (Hansen and Stepputat 2005: 34)

At the inaugural Pravasi Bharatiya Divas (Global Indian Diaspora) in 2003, the Indian government proposed dual citizenship rights for Indian nationals of the US, UK, Canada, and Australia. At the 2008 Bharatiya Pravasi Divas, Indian Prime Minister Manmohan Singh announced that Indian professionals with OCI cards could work in India. Krish Govender, a spokesperson for the National Association of Democratic Lawyers (NADAL), alluded to the negative impact of this kind of diasporic determinism: 'My concern is that this will breed more ethnicity in a minority population in South Africa. It will be divisive... It should be open to all South Africans in general, then it will be more equitable' (Sunday Times February 8 2009).

This relaxing of who constitutes the Indian nation seeks to cultivate allegiance to a form of global Indian citizenship transcending the nationstate. Simultaneously, Indian South Africans, 
particularly the working classes, through the ideological construct of the rainbow and exclusively race redress legislation, see the hyphen tightening rather than loosening. The nation state continues to determine citizenship, labour force opportunities, and immigration. Diaspora as transnationalism remains in tension with placebound nationalism but South Africa remains the place Indians call home (Brown 2006: 159).

The moment of suture with the 'Motherland' would also be the moment of new tensions.

\section{The New Laagers ('Defensive Camp')}

Much is made of the hypermobility of the globalised capitalist world and social science disciplines are replete with words like fluidity, mobility, transnationalism, cosmopolitanism.

But people are also creating laagers and withdrawing into them. Post-apartheid South Africa, we have seen, legally imprisons people into the category Indian (or Asian). Satellite television locks many into an imaginary world of diaspora and homeland. Money allows people to buy into gated communities. The rich can live in worlds that at once tie them in and liberate them, while the poor remain confined in townships whose socio-economic conditions see more and more young people seeing less and less hope of entering universities or the job market. The response to a "better life" is met with barely concealed cynicism.

Less visible to the "outside eye" is that Indians are simultaneously creating even narrower boundaries around them as South Indians, North Indians, Hindus, Tamils, Muslims, Telegus, Gujaratis and Hindustanis.

As apartheid reached its terminal stages, 'income inequality was narrowing among racial groups, as the position of whites was slipping and those of Asians and Africans were improving; and inequality within racial groups was becoming "at least as important" as inequality among groups' (MacDonald 2006: 136). This trend has continued post 1994 with COSATU general secretary Zwelinzima Vavi declaring in December 2008 that South Africa was 'getting more unequal and this is no longer on the basis of race but has more to do with class and living conditions' (Sunday Times 28 December 2008). Or as Seekings and Nattrass (2006: 304) put it '(a)s interracial inequality declined, so intraracial inequality rose'.

Class divisions among Indians are becoming wider and starker and is reflected by middle class Indians leaving the old neighbourhoods of Chatsworth and Phoenix and even Lenasia and moving into the formerly white areas like Queensburgh in KwaZulu-Natal (KZN) and Robertsham in Gauteng, while more affluent Indians are moving to Houghton in Gauteng and Umhlanga in KZN. Their children attend private schools where the annual fee per child is often more than what a working class Indian can expect to earn per annum. Expensive cars and homes, linkages to a non-racial elite with business interests that span the globe are what some Indian South Africans have come to see as a "normal" lifestyle.

The irony is that a poverty stricken resident of Chatsworth and an affluent Houghton-ite are categorised under the all-inclusive label "Indian". Poor Indians from township schools compete with rich Indian children with unlimited resources for limited places in schools, universities and on the job market. As Neo-liberalist policies widen class differences, race is the sole criterion for opportunities. Ironically, working class Indians labouring under the rubric of "Indian" in the new South Africa are encouraged to congeal under the shelter of Indianness. Some cross-race neighbourliness is developing in working class areas like Chatsworth, where Africans have moved in, but these instances are overwhelmed by idea of Indianness (Desai 2000) peddled by ethnic entrepreneurs and reinforced by the way redress is determined at the legal level.

How do/should the "poors' react? Do they break boundaries that can reach for a working class politics? Or do they become more and more inward looking ... reaching for ethnic / racial identities as a means of defence?

\section{AffirmativeAction}

On 4 December 2008 the authors were invited to a commemoration in the largely working class township of Phoenix on the north coast of KwaZulu Natal to mark the arrival of the indentured as well as discuss the 'way forward' for Indians. The panel included Sdumo Dlamini, the president of COSATU. Affirmative action and access to resources dominated the discussion. Why do "we" have to pay school fees and "they" don't? 'I work at the docks and they employed 200 casual workers last week. Why were no Indians employed?' 'They put three or four Indian 
families with a few hundred Blacks. How can we retain our culture?' And so it went on. This tiesin with a point made by political scientist Sanusha Naidu in an unpublished report to the ANC in 1999:

Within the new political dispensation, the Indian working class perceive their existence as an uncertain one. Their concerns and fears are real. Many are unsure of their future under an African government.... [They] see the ANC as preserving the interests and needs of the African people vis-à-vis the Indian worker (quoted in Desai and Maharaj 2007: 83).

Simultaneously, there was a crisis at the University of KwaZulu-Natal during November 2008 involving disciplinary action against physicist Professor Nithia Chetty and Professor van den Berg for publicly commenting on their failure to get the Senate to discuss academic freedom. The debate was played out in the public sphere through newspapers and e-mail. Chetty and ven den Berg saw this as a curtailment of academic freedom while (mainly) African academics viewed it as blocking transformation. Chetty reflected that there was a 'routine use of racial stereotyping ... practised at the highest level to suppress dissenting voices...' (Natal Witness 23 December 2008).

The concerns of the working class residents of Phoenix and a middle class university professor may appear similar but there is a difference. "Portability" is the buzzword as far as Indian professionals are concerned. Dubai, Sydney and London beckon. Nithia Chetty was snapped up by a leading university in South Africa. The residents of Phoenix have limited options as the jobs that were once their preserve in $\mathrm{KZN}$, in clothing factories, in the municipality, as civil servants, and bank clerks are closed to them. Under apartheid the per capital allocation for education, housing and welfare was relatively higher for Indians than Africans. ${ }^{2}$ These allocations have now been equalised and places at universities are harder to secure at the same time that jobs are harder to procure.

Salma Patel broadcast a short segment in the 6:00 am news slot on Radio SAFM on 22 February 2009 on whether and how the people of Phoenix would vote in the upcoming elections. The same issues came up. Dee's, describing himself as an SDO or "Sliding Door Operator", meaning a conductor in a taxi, said that he would not vote. Why? "The Whites had their chance, the Africans are having their chance. When will the Indian get a chance? When will we get houses?" A Mrs. Munsamy did not intend to vote. "They promised us houses during the last election. When we went to the office they said all were given away. How long can we live as squatters?" An anonymous social worker said that child abuse, drug abuse, violence, family breakdown were common in a context of widespread poverty. "Families don't know where the next meal will come from. How can they worry about other issues?" T's Govender, who said that he had lost his job to affirmative action, called on Indians to do "what their forefathers did - get an education ... but that is also hard because the schools don't work ... we can't afford university...."

Some Indians have a nostalgic yearning for the apartheid past. "Things were better when whites ruled", iron fist or not. The ANC government (hence Black African) now comes to be seen as oppressive and one-sided. This letter from Ismail Moolla of Umzinto to the Sunday Tribune Herald (1 June 2008) is typical of the feelings of the sentiments that one comes across regularly in ethnic newspapers like Post, Herald and Sunday Times Extra. 'Scrap affirmative action and employ people on merit' Moolla wrote:

The apartheid job reservation situation is being repeated right now in South Africa in the form of racist affirmative action and equity laws only this time blacks are beneficiaries.... Indian job seekers don't seem to qualify as they are not Black enough for advertised jobs.... Affirmative action is based on racial discrimination. That cannot be denied.... Employ the best man or woman on merit. By doing so, at least we will see efficiency and competency in all sectors of the economy.

There is also in townships a growing stratum of young men who are alienated, see no hope in the future and seek solace in gangs and drugs. A report by Dashen Moodley on the 8:00 am news segment on Radio SAFM stated that the drug "sugars", a mixture of heroine and cocaine, light brown in colour and wrapped in green packing from bin bags, was available in most corners of the township. Sam Pillay of the Anti-Drug Forum said that they reached arrangement with the courts to allow first time users to be treated by them and if they are drug free at the time of their court appearance they would be given one chance. According to Pillay they treat twenty cases per day and would treat many more had 
they had resources, so grave is the problem. Their parents mainly found work in the textile, leather and clothing industries, but these jobs have long evaporated as cheap imports flooded the country from the early 1990s. Class and colour act as powerful ceilings to their options. Many, for example, have a high school education but not the money to get into tertiary institutions or compete with middle class Indians who go to " Model C" schools ${ }^{3}$ and have the resources for extra tuition for limited places.

Affirmative action is construed as "fair discrimination" by the constitution to advance the previously disadvantaged. Despite the general rule that all citizens shall be treated equally, it is not unfair to discriminate in favour of previously disadvantaged groups in the labour market, universities, or Black Economic Empowerment (BEE) companies. While the Labour Relations Act 1995 envisaged claims based on personal discrimination as well as discrimination against the racial group, the Employment Equity Act (EEA) of 1998 removed reference to personal discrimination. In other words, the EEA only preserved the wider claim of skin over that of body (Desai and Ramjettan 2008: 295). To cite an everyday example, if two Indian students, one affluent and the other impoverished, were competing for a place at university, considerations of body and skin would have enhanced the working class students' chances. In their present form affirmative action measures are blind to class.

Focus on racial representation in broad brushstrokes, relying on the still largely valid equation of blackness with disadvantage, needs reexamining given the ever-widening economic inequality within "race" groups.

The Growth, Employment and Redistribution (GEAR) macroeconomic strategy of 1996 was touted as leading to economic redistribution, social equity, job creation and economic growth. Its trickle down promise was meant to deal with mass unemployment and poverty. Policy imperatives have been partially realised in the creation of a Black elite but the notion of trickle down has not been realised. Deepening poverty and inequality continue to define the postapartheid landscape. As MacDonald points out, pursuing 'economic equality between whites as a group and blacks as a group' is not the same as 'pursuing economic equality between whites and blacks as individuals (or blacks and blacks for that matter)....(A) rising ceiling does not lift all boats. Means can rise while medians sink, although so far, the medians are sinking without the means rising' (MacDonald 2006: 157-8).

The neo-liberal transition, while facilitating a Black middle and upper class, is deepening inequality. In trying to meet the imperatives of capital, class inequalities have exacerbated within (officially designated racial) communities and in many instances the categories of race are congealing rather than being challenged. Thus, for example, ex-President Thabo Mbeki called for the development of a Black middle class as part of the programme 'to eradicate racism' (quoted in MacDonald 2006: 156). In other words, the Black poor must support the rise of a Black middle class to eradicate racism, implying that their different class interests are the same because of their colour.

\section{Citizenship and Belonging}

When will we cease to be Africans, coloureds, Indians and so on and (simply) be Africans?...This question of representivity, at some point, ... we are going to have to look at this and say there are no Indians here, Indians are in India - they are South African. ...And these people called coloured... are probably more South African then anyone. It is becoming very difficult this mathematics.... 2004)

- Defence Minister 'Terror' Lekota (Nair

Mosiua Lekota was still part of the ruling party when he made this statement. His departure from the ANC and the formation of the Congress of the People (COPE) in late 2008 has seen the question of affirmative action return with vengeance to the national agenda, this time a predominantly African political party serving as a catalyst. Affirmative action measures, as pointed out, are class blind. In the South Africa of 2009, class matters as much as race in the context of deepening socio-economic inequalities. Tensions persist around the need to reconcile and the need for redress. These tensions lie at the heart of the difficulties of nation building and citizenship but are also useful in the cynical world of electoral survival where the entitlement of a few may be dressed up as delivery to the many. At present, competition for elite places is confined to the elite itself. The agenda, we believe, should be to build class into a transformatory agenda to achieve more 
meaningful change for a wider sector of South Africans.

That would be a good start to get people to "belong" to this broader entity "South Africa". To belong implies to be a part of or connected with something. It assumes voluntary membership by those who constitute a self-generated group. Rather than expressing freedom of association, belonging may emanate from a command or allotment. In contemporary South Africa, for example, "belonging" is often thrust upon one (by racial categorisation in the census for example). One of the worst forms of assigning belonging has been the xenophobic pogroms against African immigrants in May 2008. Assigning belonging reinforces the boundaries between groups when certain perceptions and attributes are accepted regarding who people are in terms of group belonging, and in the expectation of how they will behave.

The problem with undoing belonging is that these categories can become essentialised. One consequence is chauvinism. Some have embraced the label "Indian" and use it to assign those different from them a belonging of their own. And so tensions exist between belonging to South Africa, belonging to the rainbow nation, belonging to one's "race" group, or belonging more narrowly to one's religious, ethnic, class, or language group.

While the rise of India as a global power, the communications revolution, and offer of partial citizenship, demonstrates a certain pride in the idea of India as ancestral home and may even have an emotional attachment for some, this is a far cry from the idea of deterritorialised allegiance. The allegiance of the majority of Indians remains to the country of their birth. Yet the way in which life opportunities are laid out, makes it difficult for them to feel included, a part of the nation state. Marketisation of education and health and commodification of basic services, a process that turns citizens into customers, have marginalized poorer Indians. There has historically been a chasm between the call for unity on the part of inclusive-minded leadership and the Indian majority whose concerns often concentrated narrowly on bread-and-butter issues. The life opportunities of working class Indians remain constricted and this may increase the pull of the cultural brokers and ethnic politicians like Amichand Rajbansi whose party, the Minority Front, claims significant support among working class Indians.

\section{0 - An Assessment}

The phenomenon of diasporas calls for reimagining the "areas" of area studies and developing units of analysis that enable us to understand the dynamics of transnational cultural and economic processes, as well as to challenge the conceptual limits imposed by national and ethnic/ racial boundaries (Lavie and Swedenburg 1996: 14).

If one gazes over the twentieth century one is struck by the way "Indian" identity has been constructed, deconstructed and re-made. A central dynamic has been the tension between the way the state has tried to define it and exclude impulses from below that sought inclusion in the ruling class on the basis of Indians being "civilised" (pre-1914), to Indians being incorporated as a racial group (1914-1948), and inclusion as South Africans (both during apartheid and post-1994). Indians have through this time been variously "coolies", British subjects, colonial-borns, aliens, Indians, non-whites, Black, and all the way back to "Indian" South African, reinforcing Stuart Hall's point that identity and belonging are 'not a fixed essence at all, lying unchanged outside history and culture' (Hall 1994: 395).

That there is a multiplicity of identities is evident. In recent times Hindus have been influenced by the rise of the BJP (Bharatiya Janata Party); Tamils by the struggles in Sri Lanka; and Muslims by the Global War on Terror. The role of India in imaging a South African identity has been present from the time of their arrival. As Parvathi Raman reminded us, its significance at different historical conjunctures has depended as much on national as international factors. The attractions in 1947 may have been an independent homeland, now it is part of the contradictions of a global neoliberal political economy, which seems to be encouraging retreat into separate identities globally, with the added complexities of a South Africa trying to redress past inequities through race-based policies. Reference to the multiplication of identities as opposed to "pure master identities" is not to suggest complete flux or a movement beyond materialism. Indian South Africans cannot escape being "Indian" in the local context and we expect distinctive religious and cultural identities to persist while identification with a global diaspora will most likely strengthen. What is it that binds this diasporic community? Is it 
Bollywood, the internet, or global organi-sations like the Global Organisation of People of Indian Origin (GOPIO) and Vishwa Hindu Parishad? The answer is not clear but the spine of the diaspora is the idea of an 'imagined homeland' made real everyday in the homes of Indian South Africans through satellite television. It is this 'real virtuality' that allows 'unprecedented temporal immediacy to social events and cultural expressions' (Castells 2000: 490) that pulls it together.

Affirmative action, BEE, and talk about (re)forming the NIC all point to the tensions among Indians on how best to assert their belonging in Africa. Despite being "at home" in South Africa and their public visibility through cuisine, dress and festivals, many feel that they are 'not deemed to be self-evidently the face of the nation' (Mishra 2007: 39). The present conjuncture, as much as it closes down, also opens possibilities to debate issues of identity and belonging. This will to a large extent depend on the national transformatory project. Several trajectories are evident and require further investigation. If access to resources continues to be defined exclusively by race then one can expect increasing frustration on the part of many of the poors who see no "escape route" from the poverty in which they are mired and who will most likely be susceptible to racial and ethnic overtures from parties like the Minority Front as well as middle class ethnic "brokers". For them, identification with the "homeland" may be a way to secure pride and dignity. There are also increasing "connections" between the Indian and white middle classes. Living in the same gated communities, their children going to the same schools, enjoying the same sports like cricket and golf, having the same "problems" of crime and affirmative action has unquestionably led to a bonding. The struggles of Chetty and van den Berg at UKZN, Indian and white against a (mainly) African opposition, typifies struggles taking place at many sites across the country.

But alliances do not follow neat class lines. The professional strata both in the public and private sector feel the ceiling created by affirmative action intensely. But there are just as many Indians who, while strengthening links with the homeland, are exploiting their Indianness to gain access to resources through BEE programmes. The links between Jacob Zuma and Indian businessman Shabir Shaik have been well publicised over the past decade. When corruption charges against Zuma were officially dropped on 7 April 2009, the Post newspaper carried the story under the headline 'Zumalation in KZN' with a colour photograph of prominent Indians at the home of businessman Roy Moodley holding a party to celebrate the "victory'. Aside the reinforcing the image of the "corrupting" and "conniving" Indian, the report was revealing in important ways. It referred to the fact that 'the elite, wealthy Indian business community in KZN have pledged their unwavering support for ANC president Jacob Zuma in the April 22 general elections.... Food and drinks flowed freely at Moodley's lush home.' Moodley emphasised that Zuma was 'a fair man. Indian people are considered as favourable candidates for BEE deals and will be considered for lucrative contracts' (Post 8-14 April 2009). Here is the making of a class alliance with African beneficiaries of BEE.

Having adopted neoliberal policies, the ANCled government has to constantly straddle between a rhetoric of equality and the imperatives of capital. These policies are also the reason why class differences within communities have been exacerbated even while narrow essentialised identities are being embraced. One way to begin addressing this would be to redistribute resources under the generic banner of the poor. This would of course mean re-examining the ANC government's neoliberal economic policies. This may well lead to a class alliance among the working classes, notwithstanding the fraught attempts of the past, particularly in the 1940s and 1980s, when Indian and African workers who shared many similar problems and issues, failed to forge a sustained class alliance.

There has been a (re)turn to the language of class in many communities in South Africa, if not explicitly then at least implicitly. The languages of class oppression is one powerful way in which the Indian poor can begin to forge alliances with the African poor and in this process challenge both the laager of ethnic identity and poverty.

The language of "non-racialism" too, whatever its lack of coherence and explication, still has a powerful resonance in South Africa for many and so does the quest to build a more equitable society. Post-apartheid South Africa remains ripe with possibilities. With increasing arguments for class to be brought into the equation this may be an important stimulus for embracing identities that cross racial boundaries. 


\section{NOTES}

1 The three days of rioting left 142 people dead and 1,087 injured. In addition, 768 assaulted Indians were treated in hospital and 2,590 treated in refugee camps which had been set up in community halls, schools, temples and mosques all over Durban by volunteer doctors to attend to the injured and homeless. On 17 January 1949, 44,738 Indians were housed in such camps. 268 Indian homes were looted and completely burnt and 1,690 were partially destroyed and looted. 47 Indian businesses were totally burnt and 791 partially destroyed and looted. Indian-owned vehicles to the value of $£ 49,980$ were destroyed.

2 Upward mobility among many Indian post- 1960 was due in large measure to the expansion in education. The control of Indian education shifted to a Department of Indian Affairs in 1965 and free and compulsory education was available from 1970. The rapid increase in the building of schools resulted in adequate space for all by 1983 . The success of this growth can be seen in the fact that the number that passed the Senior Certificate examination (12 years schooling) increased from 1,496 in 1968 to 9,056 in 1984. The enlargement of the M.L. Sultan Technical College, and establishment of the Springfield College of Education and the University of Durban-Westville in the mid-1960s increased the number of Indian professionals and artisans.

3 A Model C school is one that under apartheid was reserved for the white racial group and continues to have better resources and facilities into the postapartheid period.

4 Section 9(1) of the Constitution of the Republic of South Africa (Act No. 108 of 1996) provides that all are equal before the law and have the right to equal protection and benefit of the law. Section 9(2) outlines steps that may be taken to protect or advance persons or categories of persons disadvantaged by unfair discrimination. Sections 9(3) and 9(4) provide that neither the state nor any other person may unfairly discriminate directly or indirectly against anyone on various stipulated grounds such as race, gender, sex, age, disability, culture and so forth. Section 9(5) imposes a presumption that differential treatment on one or more of the listed grounds is unfair unless it is established that such discrimination is fair.

\section{REFERENCES}

American King James Version. 'Exodus 2'. From http:// kjv.us/exodus/2.htm. (Retrieved October 27, 2009)

Brown JM 2006. Global South Asians. Introducing the Modern Diaspora. Cambridge: Cambridge University Press.

Castells M 2000. The Information Age: Economy, Society and Culture, Volume 1: The Rise of the Network Society. Oxford: Blackwell.

Cohen R 1997. Global Diasporas: An Introduction. London: UCL Press.

Coetzee JM 1995. 'Retrospect: the World Cup of Rugby,'
Southern African Review of Books, July-August. From http//web.archive.org/web/20001001002444/ www.uni-ulm.de/ rturrell/ anthro4html/CoetzeeJ. html (Retrieved October 15, 2009)

Desai A 2000. The Poors of Chatsworth. Durban: Madiba Publishers.

Desai A and Maharaj B 2007. The Making and (Re)making of Ethnic Identity: The Case of Indian South Africans. The Oriental Anthropologist 6: 72-90.

Desai A and Vahed G 2007. Inside Indenture. A South African Experience, 1860-1914. Durban: Madiba Publishers.

Desai A and Ramjettan D 2008. Sport for all? Exploring the boundaries of sport and citizenship in "liberated" South Africa. In: Adam Habib and K Bentley (Eds.): Racial Redress and Citizenship in South Africa, Cape Town: HSRC Press, pp. 289-314.

Erasmus Z 2001. (Ed). Coloured by History, Shaped by Place: New Perspectives on Coloured Identities. Cape Town: Kwela Books and SA History Online.

Frederikse J 1990. The Unbreakable Thread: NonRacialism in South Africa. Bloomington: Indiana University Press.

Guha R 2007. India after Gandhi. London: Pan Books.

Hall S 1994. Cultural identity and diaspora. In: P Williams and L Chrisman (Eds.): Colonial Discourse and PostColonial Theory. Columbia: Columbia University Press, pp. 392-401.

Hansen T and Stepputat F 2005. Introduction. In: T Hansen and F Stepputat. (Eds.). Sovereign Bodies: Citizens, Migrants, and States in the Postcolonial World. Princeton: Princeton University Press, pp. 1-36.

Hobsbawm E 1996. Ethnicity and Nationalism in Europe Today. In: Mapping The Nation, Balakrishnan, G (ed), London, Verso, pp. 255-66.

Joshi PS 1942. Tyranny of Colour. London: Associated Faculty Pr Inc. (Republished 1973).

Lavie S and Swedenburg T 1996. Displacement, Diaspora and Geographies of Identity. Durham: Duke University Press.

MacDonald M 2006. Why Race Matters in South Africa. Scottsville: University of KwaZulu-Natal Press.

Manas, 'The Future of Indians in the Diaspora.' From http://www.sscnet.ucla.edu/southasia/Diaspora/ future.html (Retrieved May 15, 2009)

Mbeki G 1992. The Struggle for Liberation in South Africa: A Short History. Cape Town: David Philip.

Mishra V 2007. The Literature of the Indian Diaspora. Theorizing the Diasporic Imaginary. London: Routledge.

Nair, K 2 June 2004. Let's just be South Africans - Lekota. From http://www.iol.co.za/index.php?click_id=6\& art_id=vn20040602011959357C312223\&set_id=1 (Retrieved May 29, 2009)

Said E 1993. Culture and Imperialism, New York: Alfred Knopf.

Seekings J and Natrass N 2006. Class, Race, and Inequality in South Africa. Scottsville: University of KwaZuluNatal Press.

Simmel G 1964. The Stranger. In: Kurt H Wolff (Ed). The Sociology of Georg Simmel. New York: The Free Press. 
Sparks A 1994. Tomorrow is Another Country: The Inside Story of South Africa's Negotiated Settlement. Johannesburg: Struik.

van der Veer P 2005. Virtual India: Indian IT Labour and the Nation-State. In: T Hansen and F Stepputat. (Eds,): Sovereign Bodies: Citizens, Migrants, and States in the Postcolonial World. Princeton: Princeton University Press, pp. 267-291. 